\title{
Sequence Diversity Within the Three Agents of Groundnut Rosette Disease
}

\author{
C. M. Deom, R. A. Naidu, A. J. Chiyembekeza, B. R. Ntare, and P. Subrahmanyam
}

First author: Department of Plant Pathology, Plant Sciences Building, The University of Georgia, Athens 30602-7274; second and fifth authors: Genetic Resources and Enhancement Program (GREP), International Crops Research Institute for the Semi-Arid Tropics (ICRISAT), P.O.

Box 1096, Lilongwe, Malawi; third author: Department of Agricultural Research and Technical Services, Chitedze Agricultural Research

Station, Lilongwe, Malawi; fourth author: GREP, ICRISAT, P.O. Box 320, Bamako, Mali.

Current address of R. A. Naidu: Department of Plant Pathology, The University of Georgia, Athens 30602-7274.

Accepted for publication 5 December 1999.

\begin{abstract}
Deom, C. M., Naidu, R. A., Chiyembekeza, A. J., Ntare, B. R., and Subrahmanyam, P. 2000. Sequence diversity within the three agents of groundnut rosette disease. Phytopathology 90:214-219.

Sequence diversity was examined in the coat protein (CP) gene of Groundnut rosette assistor virus (GRAV), the overlapping open reading frames (ORFs) 3 and 4 of Groundnut rosette virus (GRV), and the satellite RNA (sat-RNA) of GRV obtained from field isolates from Malawi and Nigeria. These three agents cause groundnut rosette disease, a major disease of groundnut in sub-Saharan Africa (SSA). Sequence analysis showed that the GRAV CP gene was highly conserved (97 to 99\%) independent of its geographic source. The nucleotide sequence of the overlapping ORFs 3 and 4 of GRV was highly conserved (98 to 100\%) from

isolates within a geographic region but less conserved ( 88 to $89 \%$ ) between isolates from the two distinct geographic regions. Phylogenetic analysis of the overlapping ORFs 3 and 4 show that the GRV isolates cluster according to the geographic region from which they were isolated, indicating that Malawian GRV isolates are distinct from Nigerian GRV isolates. Similarity within the sat-RNA sequences analyzed ranged from 88 to $99 \%$. Phylogenetic analysis also showed clustering within the sat-RNA isolates according to country of origin, as well as within isolates from two distinct regions of Malawi. Because the GRAV CP sequence is highly conserved, independent of the geographic source of the GRAV isolates, the GRAV CP sequence represents the most likely candidate to use for pathogen-derived resistance in groundnut and may provide effective protection against groundnut rosette disease throughout SSA.
\end{abstract}

Groundnut rosette disease (GRD) is the most destructive virus disease of groundnut (peanut, Arachis hypogaea L.) in sub-Saharan Africa (SSA) (22). It is caused by a complex of three agents: Groundnut rosette assistor virus (GRAV) (9,17,31), Groundnut rosette virus (GRV) $(18,28,35)$, and the satellite RNA (sat-RNA) $(18,19)$ of GRV. An aphid, Aphis craccivora Koch., transmits the disease in a persistent and circulative manner $(8,32)$. Disease symptoms occur in two predominant forms, chlorotic and green rosette, although other symptomatic forms have been reported $(21,25,33)$.

The intimate interaction between GRAV, GRV, and sat-RNA is crucial to the development of the disease. GRV, a member of the genus Umbravirus, has a single-stranded, positive-sense RNA genome of 4,019 nt (35) that contains four large open reading frames (ORFs). ORF 2 is a putative RNA-dependent RNA polymerase and is likely expressed as a fusion protein with the product of ORF1 by a -1 frameshift mechanism. The $3^{\prime}$ ORFs ( 3 and 4 ) are almost completely overlapping. The protein encoded by ORF 3 was shown to be a trans-acting long-distance movement protein that can traffic nonrelated viral RNA systemically (30), while analysis of the ORF 4 putative amino acid sequence suggests that it may be involved in cell-to-cell movement (35). GRV acts as a helper virus for replication of sat-RNA. Sat-RNA (895 to $903 \mathrm{nt}$ ) is not required for GRV replication or infection but is required for aphid transmission of GRV (18). The sat-RNA is primarily responsible for inducing the different symptoms of GRD, while GRAV and GRV appear to contribute very little to disease symptoms (19). GRAV, a member of the genus Luteovirus, acts as a helper virus for aphid transmission of GRV and sat-RNA. GRV, which does

Corresponding author: C. M. Deom; E-mail address: deom@arches.uga.edu.

Publication no. P-2000-0121-01R

(C) 2000 The American Phytopathological Society not encode a coat protein (CP), and sat-RNA are packaged, presumably together, in the CP of GRAV to form particles that are aphid transmissible $(18,29)$. A single aphid vector acquires GRAV, GRV, and sat-RNA; however, it does not always transmit the three disease agents together to a host plant (23): GRAV or GRV plus sat-RNA can be transmitted separately. However, for the disease to perpetuate in nature, all three agents must be transmitted by the aphid vector to a plant.

In recent years, efforts to control GRD have focused on improving cropping practices to delay the onset and spread of both the vector and the disease and on breeding for host-plant resistance. Cropping practices have led to effective management practices for controlling GRD (20); however, the approach is seldom feasible for the subsistence farming systems of SSA. In the case of host-plant resistance, the resistance that is available is against GRV and can be overcome under high inoculum pressure $(3,24$, 26). Resistance is not yet available in different genetic backgrounds of groundnut suitable for the diverse seasons and farming systems of SSA. No resistance has yet been reported against GRAV.

Pathogen-derived resistance (PDR) $(1,4)$ represents an alternate strategy for controlling GRD through the generation of transgenic groundnut. PDR could potentially be obtained by introducing GRAV or GRV genomic sequences or genes, or sat-RNA-derived sequences that down regulate GRV replication, into suitable groundnut cultivars. The success of PDR-, RNA- or protein-mediated $(1,4)$ resistance, is highly influenced by the degree of sequence homology between the sequence of the transgene and the challenging virus $(4,14)$.

As a first step toward developing PDR, the degree of variability within the three disease agents of GRD from two diverse groundnut-growing regions of SSA was examined to identify a sequence or sequences from the disease agents that is highly conserved and therefore a good candidate to confer PDR to GRD throughout SSA. Variability was examined within the CP gene of GRAV, the over- 
lapping ORFs 3 and 4 of GRV, and the sat-RNA from field isolates obtained from Malawi (southern Africa) and Nigeria (West Africa).

\section{MATERIALS AND METHODS}

Virus and sat-RNA isolates, reverse transcriptase polymerase chain reaction, and cloning. GRD-infected groundnut plants were collected from fields near Lilongwe and Karonga, Malawi, and from fields near Bagouda and Kofa, Nigeria (Table 1). Total RNA was extracted from leaf tissue using a RNeasy Plant Mini Kit (Qiagen, Chatsworth, CA). First-strand cDNAs of GRAV CP genes, GRV ORFs 3 and 4, or sat-RNAs were synthesized from 2.5 to $5.0 \mu \mathrm{g}$ of RNA using the Superscript Preamplification System (Gibco BRL, Gaithersburg, MD). Primers used for first-strand cDNA synthesis of GRAV CP genes, GRV ORFs 3 and 4, and satRNAs were GRAV3, C3, and Sat31 (Table 2), respectively. Firststrand cDNA was amplified by polymerase chain reaction (PCR) with the following primers. The CP gene of GRAV was amplified with the primers GRAV5 and GRAV3 (Table 2). GRV ORFs 3 and 4 (96\% of ORF 4 from the $5^{\prime}$ terminus overlaps with ORF 3 in the PCR product obtained) were amplified with primers S3 and C3 (Table 2) (35). Sat-RNAs were amplified with primers SAT51 and SAT31 (Table 2) (2). One of two procedures was used to obtain PCR products. Procedure 1: PCR reactions (100 $\mu \mathrm{l})$ contained $3.0 \mu \mathrm{l}$ of first-strand cDNA, $1 \times P f u$ Turbo DNA polymerase buffer, $0.2 \mathrm{mM}$ dNTPs, $0.4 \mu \mathrm{M} \mathrm{5} 5^{\prime}$ primer, $0.4 \mu \mathrm{M} 3^{\prime}$ primer, and $2.5 \mathrm{U}$ of $P f u$ Turbo DNA polymerase (Stratagene, La Jolla, CA). PCR was programmed for 30 cycles of $30 \mathrm{~s}$ at $94^{\circ} \mathrm{C}, 60 \mathrm{~s}$ at $55^{\circ} \mathrm{C}$, and $5 \mathrm{~min}$ at $72^{\circ} \mathrm{C}$, preceded by an initial denaturation for $1 \mathrm{~min}$ at $94^{\circ} \mathrm{C}$ and followed by a $10 \mathrm{~min}$ extension at $72^{\circ} \mathrm{C}$. Procedure 2: PCR reactions $(100 \mu \mathrm{l})$ contained $3.0 \mu \mathrm{l}$ of first-strand cDNA, $1 \times$ AmpliTaq DNA polymerase buffer II, $1.5 \mathrm{mM} \mathrm{MgCl} 2,0.2 \mathrm{mM}$ dNTPs, $0.4 \mu \mathrm{M}$ $5^{\prime}$ primer, $0.4 \mu \mathrm{M} 3^{\prime}$ primer, and $2.5 \mathrm{U}$ of AmpliTaq DNA polymerase (Perkin Elmer, Norwalk, CT). PCR was programmed for 30 cycles of $30 \mathrm{~s}$ at $94^{\circ} \mathrm{C}, 60 \mathrm{~s}$ at $55^{\circ} \mathrm{C}$, and $3 \mathrm{~min}$ at $72^{\circ} \mathrm{C}$, preceded by an initial denaturation for $1 \mathrm{~min}$ at $94^{\circ} \mathrm{C}$ and followed by a 10-min extension at $72^{\circ} \mathrm{C}$. Amplified products were purified from $0.8 \%$ agarose gels using a QIAEX II Gel Extraction Kit (Qiagen) and cloned into pPCR-Script AMP SK(+) (Stratagene) if the PCR product was obtained with $P f u$ Turbo DNA polymerase or into pGEM-T (Promega Corp., Madison, WI) if the PCR product was obtained with AmpliTaq DNA polymerase.

Nucleotide sequencing and sequence analysis. At least two independent clones from each PCR reaction were sequenced in both directions (Molecular Genetics Instrumentation Facility, University of Georgia, Athens). If differences were detected, a third PCR product was sequenced, and a consensus sequence was obtained. In cases where three PCR products were sequenced, no more than one nucleotide difference was detected at a position. Nucleotide and predicated amino acid sequences were aligned and

TABLE 1. Sources of groundnut rosette disease (GRD) infectious agents

\begin{tabular}{llll}
\hline $\begin{array}{l}\text { Infected } \\
\text { plant }\end{array}$ & \multicolumn{1}{c}{ Origin } & $\begin{array}{c}\text { Groundnut } \\
\text { cultivar }^{\mathrm{a}}\end{array}$ & $\begin{array}{c}\text { GRD symptom } \\
\text { phenotype }\end{array}$ \\
\hline M8 & Karonga, Malawi & Malimba & Green \\
M11 & Karonga, Malawi & Malimba & Green \\
M12 & Karonga, Malawi & Malimba & Chlorotic \\
M14 & Karonga, Malawi & Malimba & Green \\
M16 & Karonga, Malawi & Malimba & Green \\
M17 & Karonga, Malawi & Malimba & Chlorotic \\
M24 & Lilongwe, Malawi & JL24 & Chlorotic \\
N15 & Bagouda, Nigeria & ND & Chlorotic \\
N17 & Kofa, Nigeria & ND & Green \\
N19 & Kofa, Nigeria & ND & Chlorotic \\
N27 & Bagouda, Nigeria & ND & Green \\
N29 & Bagouda, Nigeria & ND & Green \\
N310 & Bagouda, Nigeria & ND & Chlorotic \\
\hline
\end{tabular}

${ }^{\text {a }} \mathrm{ND}=$ not determined. compared using DNASIS (Hitachi, San Bruno, CA). Phylogenetic trees were generated by the neighbor-joining method using PAUP (Sinauer Associates, Inc., Sunderland, MA). Bootstrap values were determined from 1,000 replicates.

\section{RESULTS}

Sequence of the GRAV-CP gene. The nucleotide and amino acid sequences of cloned CP genes from eight field isolates of GRAV obtained from Malawi (M8GCP, M11GCP, M12GCP, and M16GCP) and Nigeria (N15GCP, N17GCP, N19GCP, and N29GCP), as well as a previously published GRAV-CP sequence (designated GCPP in this report) (31) were compared. The published GRAV CP sequence was obtained from a GRAV isolate maintained in groundnut by aphid or graft inoculation (31). The GRAV CP clones are designated by the name of the infected plants the isolates were

TABLE 2. Oligonucleotide primers used for reverse transcriptase polymerase chain reaction (RT-PCR)

\begin{tabular}{|c|c|c|}
\hline $\begin{array}{l}\text { RT-PCR } \\
\text { primer pairs }\end{array}$ & Sequence & $\begin{array}{l}\text { RT-PCR product } \\
\text { size (nt) }\end{array}$ \\
\hline GRAV5 ${ }^{\mathrm{a}}$ & 5'-ATGAATACGGTCGTGGTTAGG-3' & 597 \\
\hline GRAV3 ${ }^{b}$ & 5'-TTTGGGGTTTTGGACTTGGC-3' & \\
\hline $\mathrm{S} 3^{\mathrm{a}, \mathrm{c}}$ & $5^{\prime}$-GGAAGCCGGCGAAAGCTACC-3' & 864 \\
\hline $\mathrm{C}^{\mathrm{b}, \mathrm{c}}$ & 5'-GGCACCCAGTGAGGCTCGCC-3' & \\
\hline SAT51a & 5'-GGGTTTCAATAGGAGAGTTGC-3' & $893-901$ \\
\hline SAT $31^{\mathrm{b}}$ & 5'-AAATGCCTAGTTTGGGCGTG-3' & \\
\hline
\end{tabular}

${ }^{a}$ Sense-strand primer.

${ }^{\mathrm{b}}$ Complementary-strand primer.

c S3 and C3, used to obtain Groundnut rosette virus open reading frames 3 and 4 , have been described previously (35).

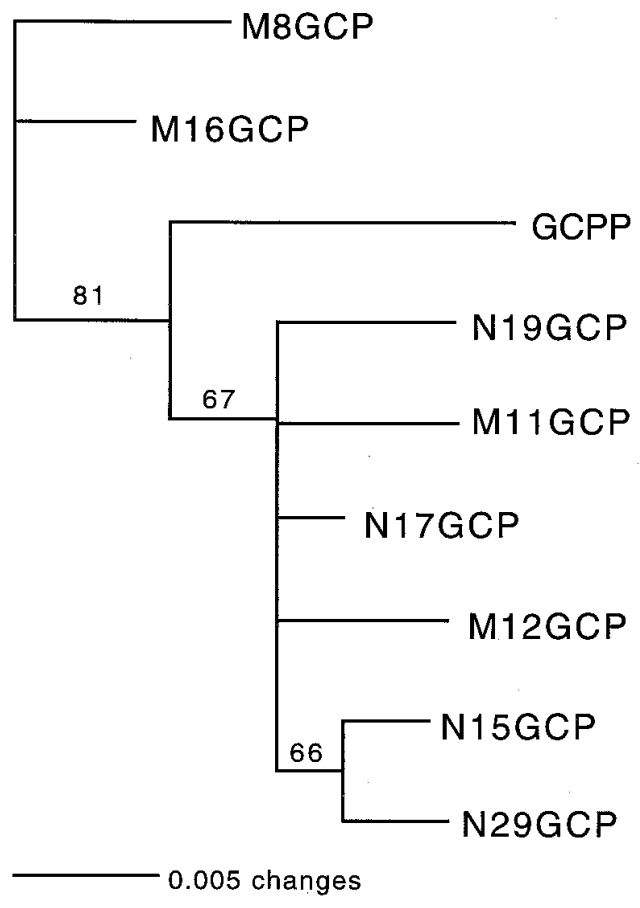

Fig. 1. Phylogenetic analysis of the nucleotide sequence of the coat protein (CP) genes obtained from nine isolates of Groundnut rosette assistor virus (GRAV). GenBank accession numbers for the GRAV CP genes are in parenthesis following isolate designations. Clones of $\mathrm{CP}$ genes from field isolates from Malawi are M8GCP (AF195502), M11GCP (AF195503), M12GCP (AF195823), and M16GCP (AF195824). Clones of CP genes from field isolates from Nigeria are N15GCP (AF195825), N17GCP (AF195826), N19GCP (AF195827), and N29GCP (AF195828). The sequence of the GCPP isolate was described previously (31). Phylogenetic trees were generated by the Neighbor-Joining Method of PAUP. Numbers represent bootstrap values determined from 1,000 replicates. Nodes with bootstrap values $<60 \%$ were collapsed. 
derived from (Table 1) followed by GCP (e.g., M8GCP). The nucleotide sequence of the CP genes was highly similar, 97 to $99 \%$ identical. Similarly, the amino acid sequence of the GRAV CPs was 97 to $100 \%$ identical. A phylogenetic analysis of the GRAV CP nucleotide sequences showed that the isolates did not strictly group according to their provenance (Fig. 1). Two of the Malawian isolates, M11GCP and M12GCP, grouped with the four Nigerian isolates, as did GCPP. Malawian isolates M8GCP and M16GCP grouped separately.

Sequence of GRV ORFs 3 and 4. Reverse-transcriptase (RT)PCR products encompassing all of GRV ORF 3 and most of the overlapping ORF 4 (96\%) were cloned from eight field isolates of GRV from Malawi (M12GRV, M14GRV, M16GRV, and M17GRV) and Nigeria (N15GRV, N17GRV, N19GRV, and N27GRV). The GRV clones are designated by the name of the infected plants (Table 1) the isolates were obtained from followed by GRV (e.g., M12GRV). Comparisons were made between the nucleotide and predicted amino acid sequences of ORF 3 and 4 from the Malawian and Nigerian isolates, as well as from a previously published Malawian GRV isolate (designated ORF3P and ORF4P) (35). The percentage of nucleotide identity within the Malawian field isolates or within the Nigerian isolates was 98 to $100 \%$ for both ORFs 3 and 4, while the nucleotide identities between the Malawian and Nigerian isolates were more variable (88 to $89 \%$ for both ORFs). The observation that the nucleotide sequence similarities were more conserved from field isolates obtained from within a distinct geographic region was confirmed by phylogenetic analysis (Fig. 2). Curiously, GRV ORF3P and ORF4P were more similar to the Nigerian isolates (Fig. 2). The nucleotide

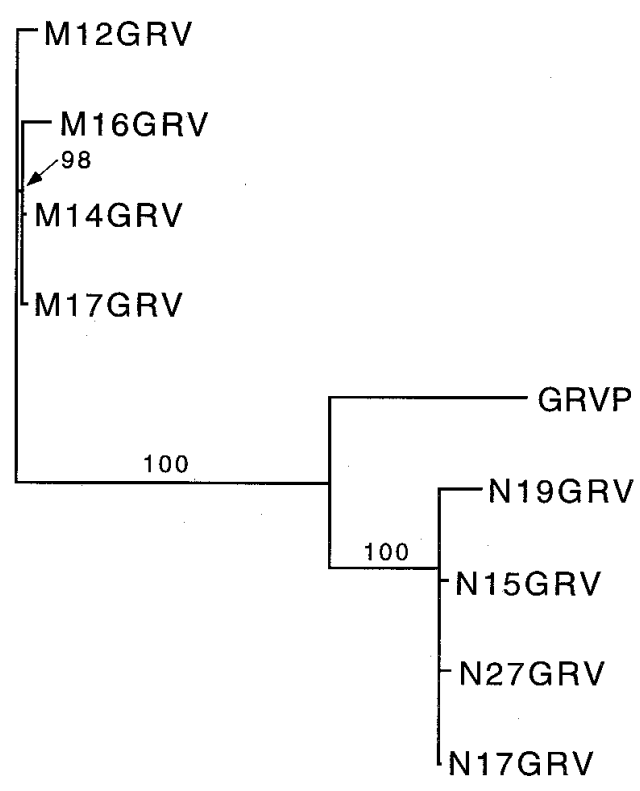

0.01 changes

Fig. 2. Phylogenetic analysis of the nucleotide sequence of overlapping open reading frames (ORFs) 3 and 4 obtained from nine isolates of Groundnut rosette virus (GRV). GenBank accession numbers for ORFs 3 and 4 are in parenthesis, respectively, following isolate designations. Clones of field isolates from Malawi are M12GRV (AF202858, AF202871), M14GRV (AF202859, AF202872), M16GRV (AF202860, AF202873), and M17GRV (AF202861, AF202874). Clones of field isolates from Nigeria are N15GRV (AF202862, AF202875), N17GRV (AF202863, AF202876), N19GRV (AF202864, AF202877), and N27GRV (AF202865, AF202878). The nucleotide sequence of the overlapping GRV ORF3P and ORF4P (35) (GenBank Accession no. Z69910) is given as GRVP. The phylogenetic tree of the overlapping ORFs 3 and 4 sequences is shown because individual trees for ORFs 3 and 4 were essentially identical. Phylogenetic trees were generated by the Neighbor-Joining Method of PAUP. Numbers represent bootstrap values determined from 1,000 replicates. Nodes with bootstrap values $<60 \%$ were collapsed. Arrow indicates the branch has a bootstrap value of 98 . sequence of the overlapping ORF3P and ORF4P (35) showed 93 and $92 \%$ identity, respectively, with the four Nigerian isolates and 87 to $88 \%$ identity with the Malawian isolates. GRV ORF 3 sequences from the Malawian and Nigerian field isolates were $33 \mathrm{nt}$ longer at the $5^{\prime}$ terminus than the nucleotide sequence of the published isolate, ORF3P (35). The putative amino acid sequences of the extensions at the $\mathrm{N}$ termini of the Malawian and Nigerian isolates were MDMVEHLSPER(R) and MDMAQHPPQQR(I), respectively (the amino acids in parenthesis represent the position of the first amino acid, an M, in ORF3P).

ORFs 3 and 4 shared 96 to $100 \%$ and 98 to $100 \%$ amino acid identity, respectively, between the Malawian isolates and 95 to $100 \%$ and 99 to $100 \%$ identity, respectively, between the Nigerian isolates. In contrast, ORF 3 amino acid identity between the Malawian and Nigerian field isolates was 73 to $79 \%$. Similarly, ORF3P was less conserved, showing 66 to $71 \%$ amino acid identity with the Malawian field isolates and 80 to $81 \%$ with the Nigerian field isolates. When the amino acid sequences of the ORF 3 proteins were aligned, variability between the Malawian and Nigerian isolates was distributed throughout the ORF 3-encoded proteins (Fig. 3 ), although three regions were highly conserved (amino acids 17 through 39, 168 through 192, and 227 through 262). In contrast, the amino acid identity of ORF 4 between the Malawian and Nigerian field isolates was more conserved, sharing 92 to $93 \%$ identity. The sequence of ORF4P shared 93 to $96 \%$ identity with the Malawian and Nigerian field isolates. The most variable region of

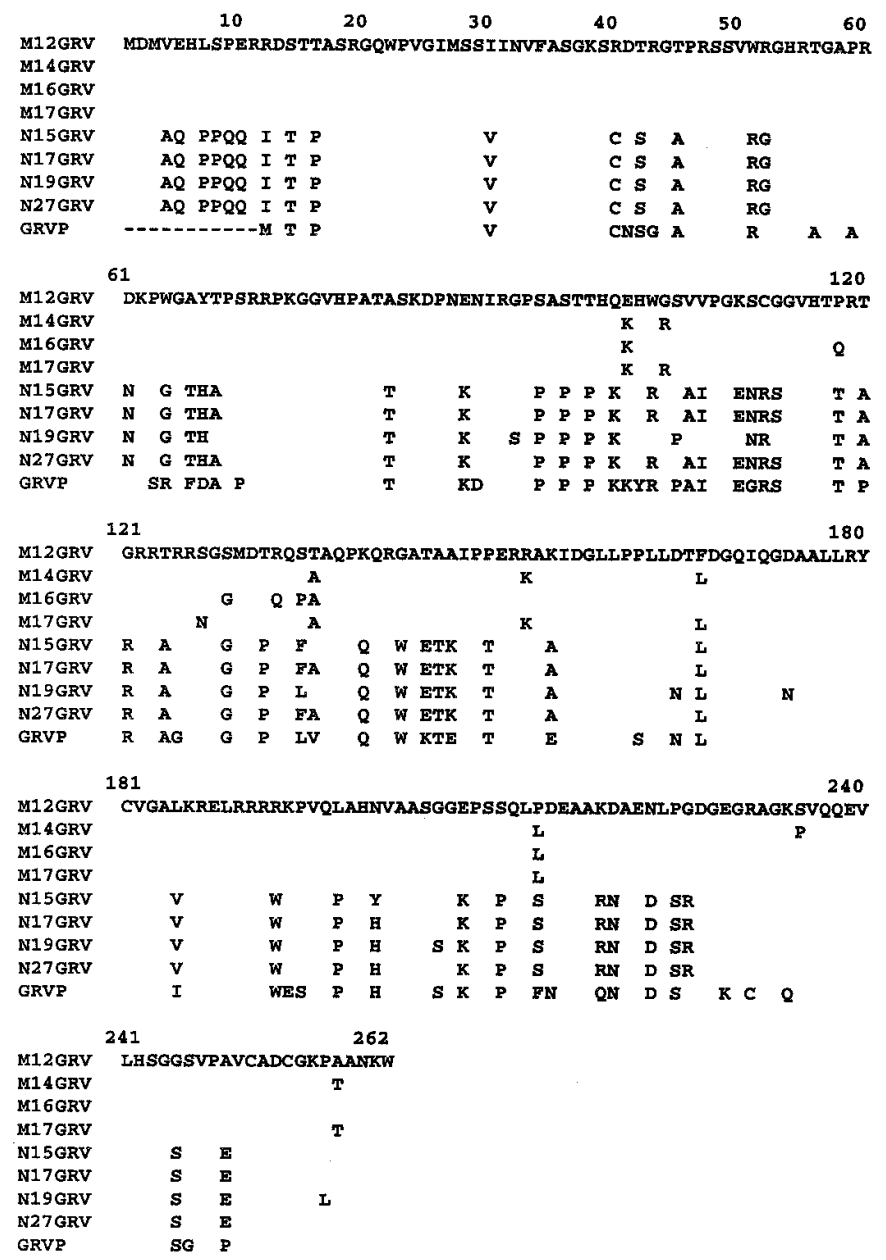

Fig. 3. Alignment of putative amino acid sequences deduced from Groundnut rosette virus open reading frame (ORF) $3 \mathrm{cDNA}$ clones. The complete sequence of clone M12GRV is shown. Sequences of the other ORF 3 cDNA clones are shown only where they differ from the sequence of M12GRV. Dashes represent spaces inserted for alignment. 
the proteins encoded by ORF 4 between the Malawian and $\mathrm{Ni}$ gerian isolates was at the $\mathrm{C}$ terminus of the proteins (Fig. 4).

Sequence of GRV sat-RNA. The nucleotide sequence of cloned sat-RNAs obtained from five infected groundnut plants from Malawi (M11S, M12S, M16S, and M24S) and Nigeria (N310S), as well as two previously published sat-RNA sequences, were compared. The sat-RNA clones are designated by the name of the infected plants from which the isolates were obtained (Table 1) followed by S (e.g., M11S). The previously published sat-RNA sequences used for comparison are from clones derived from populations associated with greenhouse-maintained GRV isolates originally obtained from a plant showing symptoms of chlorotic rosette from Malawi (MC3a) or from a plant showing symptoms of green rosette from Nigeria (NG3a) (2). The Malawian satRNAs share 88 to $99 \%$ nucleotide identity, while the two Nigerian isolates were $92 \%$ identical. Phytogenetic analysis showed that the two Nigerian isolates (N310S and NG3a) clustered together, while the Malawian isolates clustered into two groups. One of the Malawian groups (composed of M11S, M12S, and M16S) was more closely related to the Nigerian isolates than the second Malawian group (composed of M24S and MC3a) (Fig. 5).

Interestingly, a 7-nt deletion (nucleotides 37 to 43) was observed in two isolates, M11S and N310S. The deletion appears to have no effect on symptom type, nor was the deletion unique to a particular geographic region, because M11S was isolated from a plant in Malawi that showed green rosette symptoms and N310S was isolated from a plant in Nigeria that showed chlorotic rosette symptoms.

\section{DISCUSSION}

Variability within the causal agents of GRD (GRAV, GRV, and sat-RNA) was examined to identify sequences that are highly conserved to use in generating PDR to the disease in transgenic ground-

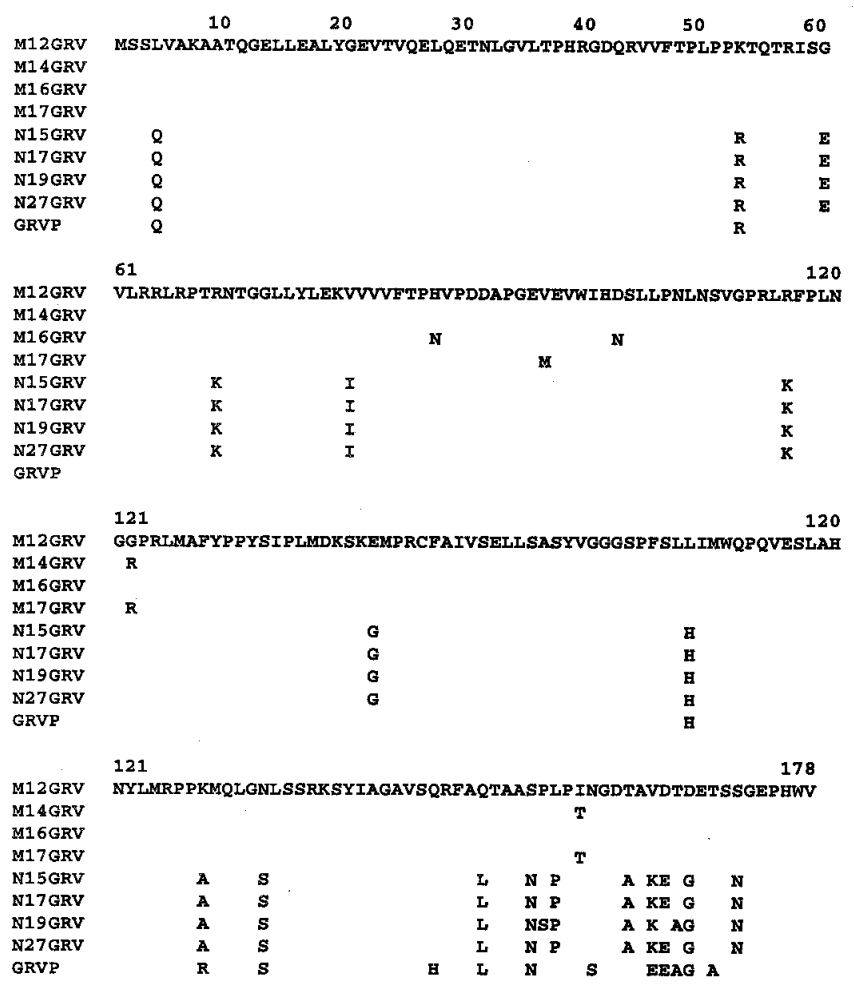

Fig. 4. Alignment of putative amino acid sequences deduced from Groundnut rosette virus open reading frame (ORF) 4 cDNA clones. The sequence of the N-terminal 178 amino acids of M12GRV is shown. Sequences of the other ORF 4 cDNA clones are shown only where they differ from the sequence of M12GRV. nut plants. The disease agents were obtained from Malawi and Nigeria, two geographically distinct regions of SSA. In most cases, the degree of PDR shows a positive correlation with the level of sequence homology between the transgene and challenge virus $(4,14)$. From the variability studies conducted, the GRAV CP gene is the logical candidate to use for generating transgenic groundnut plants for PDR. The high level of sequence homology within the GRAV-CP genes (97 to 99\%) from isolates from both Malawi and Nigeria indicates that PDR derived from the GRAV CP gene would likely be functional throughout SSA.

The utility of PDR with luteovirus CP sequences has been described $(11,12)$. Transgenic potato plants expressing the $\mathrm{CP}$ gene of Potato leafroll virus (PLRV) of the genus Luteovirus showed resistance to PLRV in both greenhouse and field trials $(11,12)$. A number of low-probability potential risks that could be associated with transgenic resistance to luteoviruses have been proposed (16). Presently, the mechanism (RNA-mediated or protein-mediated) $(1,4)$ by which the luteovirus CP gene induces PDR in transgenic plants is unknown. However, an RNA-mediated resistance mechanism would alleviate concerns for many of the potential risks, which are protein mediated (e.g., transcapsidation that might confer new vector specificity and synergistic interactions between the transgene product and an unrelated challenging virus).

Expression of the GRAV CP gene could induce PDR by two approaches. First, expression of GRAV CP in transgenic plants could result in less GRAV available for transmission. This would occur through either gene silencing (RNA-mediated) or CP-mediated resistance $(1,4)$. Second, since the $\mathrm{CP}$ of GRAV is required for the encapsidation of the GRV genome and sat-RNA $(18,29)$, the absence of or reduction in GRAV CP would presumably result in diminished packaging of GRV and sat-RNA and, subsequently, reduced aphid transmission.

The nucleotide sequence of GRV ORFs 3 and 4 from isolates from the same geographic region were 98 to $100 \%$ identical, but

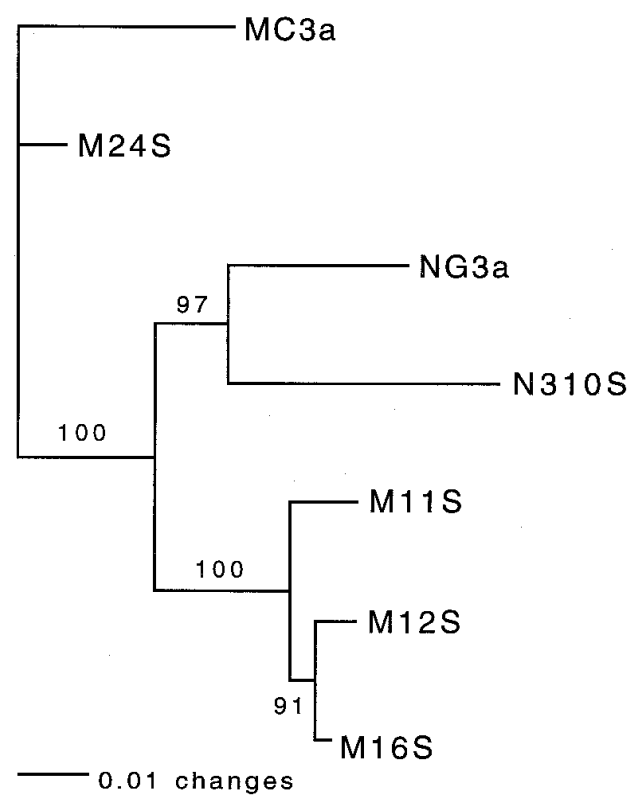

Fig. 5. Phylogenetic analysis of the nucleotide sequence of seven satellite RNA (sat-RNA) isolates. GenBank accession numbers for the sat-RNA sequences are in parenthesis following isolate designations. Clones of field isolates from Malawi are M11S (AF202866), M12S (AF202867), M16S (AF202868), and M24S (AF202869). N310S (AF202870) is a clone of a field isolate from Nigeria. Clones of two previously published isolates from Malawi, MC3a (Z29702), an isolate that induces chlorotic rosette disease symptoms, and $\mathrm{Ni}$ geria, NG3a (Z29704), an isolate that induces green rosette disease symptoms, were described previously (2). Phylogenetic trees were generated by the Neighbor-Joining Method of PAUP. Numbers represent bootstrap values determined from 1,000 replicates. 
more variability ( 88 to $89 \%$ identity) was observed between isolates from distinct geographic regions. Phylogenetic analysis indicates that the Malawian and Nigerian isolates form distinct groups (Fig. 2). The clustering of isolates from within geographic regions indicates that isolates within each group are distinct and are evolving along discrete lineages.

A high degree of identity (91 to $93 \%$ ) was observed within the putative amino acid sequences encoded by ORF 4 of the Malawian and Nigerian isolates. In contrast, a lower degree of identity (73 to $79 \%$ ) was observed between the putative amino acid sequences encoded by ORF 3 of the Malawian and Nigerian isolates, even though ORFs 3 and 4 overlap extensively. This finding suggests that the protein encoded by ORF 4, the putative cell-tocell movement protein (35), tolerates less variability than the protein encoded for by ORF 3. It is tempting to assume that variability within the ORF 3 nucleotide sequence would be higher if not for the extensive overlap of ORF 3 and 4 and the higher level of conservation, presumably required, in the protein encoded by ORF 4 . This finding suggests that overlapping genes can represent an evolutionary control mechanism, which can be a major factor in determining the level of divergence within the genes (13). This type of control is significant in virus evolution, because overlapping genes are used extensively by viruses as a genome-expression strategy $(5,15)$.

The predicted amino acid sequences of the proteins encoded by ORF 3 from the Malawian and Nigerian isolates were 11 amino acids longer at the $\mathrm{N}$ terminus than the protein encoded by ORF3P (35). The initiation codon for the protein encoded by ORF3P (nucleotides 2,641 to 2,643) was selected based on protein alignment comparisons with proteins encoded by corresponding ORFs in the Carrot mottle virus genome (a member of the genus Umbravirus) and RNA 2 of Pea enation mosaic virus (RNA 2 has strong similarities to members of the genus Umbravirus) (35). In the case of the Malawian and Nigerian isolates, the corresponding nucleotides $(2,641$ to 2,643) encode for an $\mathrm{R}$ in the Malawian isolates and an $\mathrm{I}$ in the Nigerian isolates. The $\mathrm{N}$ terminus of the protein encoded by ORF 3 of GRV is unknown; therefore, we chose the most 5 '-end initiation codon for protein analysis in this manuscript. Although we do not know the reason for this difference, it is possible that mechanical passage of GRV in $N$. benthamiana (35) resulted in the selection of a variant that no longer requires the N-terminal 11 amino acids for mechanical transmission. Therefore, we cannot exclude the possibility that the $\mathrm{N}$ terminus of the ORF 3 protein may have a function that is required for GRV infection or vector transmission in groundnut.

Sequence variability was compared in five sat-RNA field isolates and two published sat-RNA sequences. Nucleotide sequences within the sat-RNAs sequenced showed 88 to $99 \%$ identity. Two elements in the sat-RNA (element A, nucleotides 280 to 470 and element B, nucleotides 629 to 849 ) involved in symptom production in $N$. benthamiana have been described (34). However, a comparison of these elements in the sat-RNAs sequences examined here failed to indicate obvious nucleotide differences that might account for the different symptom types. Phylogenetic analysis indicates that the Nigerian sat-RNA isolates clustered together, while the Malawian isolates clustered into two groups. One Malawian group was composed of sat-RNAs obtained from northern Malawi (Karonga area: M11S, M12S, and M16S). Isolates from this group were more closely related to the Nigerian isolates than isolates from central Malawi (Lilongwe area: M24S and MC3a). This finding suggests that sat-RNAs from northern and central Malawi are diverging. The Mzuzu Plateau, which separates the Karonga area from the Lilongwe area, may act as a barrier to the free flow of GRD agents between the two regions. Indeed, while chlorotic rosette is found in both northern and central Malawi, green rosette is found only in northern Malawi.

Studies that use sat-RNAs to generate PDR appear promising $(6,7,10,36)$, although the utility of using this strategy is in ques- tion because only a few nucleotide changes can modify a satellite from a form that suppresses symptoms to one that enhances disease symptoms (27). We do not anticipate using the satellite sequences for PDR studies, but the degree of variability in sat-RNA sequences might be useful in the future in determining which nucleotide differences are involved in determining the different symptom types, as well as pathogenicity.

In all GRD resistant cultivars and germ lines that have been analyzed, resistance is to GRV $(3,26)$ not sat-RNA or GRAV. As mentioned earlier, resistance to GRV can be overcome under field conditions $(3,24,26)$, necessitating the need for additional resistance strategies. To this end, experiments to generate PDR in transgenic groundnut plants expressing a GRAV CP gene are underway. In the future, it would be advantageous to exploit a combination of virus-resistance genes and viral sequences that induce PDR to broaden the genetic base of resistance to GRD and enhance its durability.

\section{ACKNOWLEDGMENTS}

This work was supported by the Peanut Collaborative Research Support Program (Peanut CRSP) of the United States Agency for International Development (Grant LAG-G-00-96-90013-00). We thank H. Pappu and J. Sherwood for reviewing this manuscript and O. Paguio for technical assistance.

\section{LITERATURE CITED}

1. Baulcombe, D. C. 1996. Mechanisms of pathogen-derived resistance to viruses in transgenic plants. Plant Cell 8:1833-1844.

2. Blok, V. C., Ziegler, A., Robinson, D. J., and Murant, A. F. 1994. Sequences of 10 variants of the satellite-like RNA-3 of groundnut rosette virus. Virology 202:25-32.

3. Bock, K. R., Murant, A. F., and Rajeshwari, R. 1990. The nature of the resistance in groundnut to rosette disease. Ann. Appl. Biol. 117:379-384.

4. Deom, C. M. 1999. Engineered resistance. Pages 1307-1314 in: Encyclopedia of Virology, 2nd ed. A. Granoff and R. Webster, eds. Academic Press, London.

5. Fields, B. N., Knipe, D. M., and Howley, P. M., eds. 1996. Fields Virology, 3rd ed. Lippincott-Raven Publishers, New York.

6. Gerlach, W. L., Llewellyn, D., and Haseloff, J. 1987. Construction of a plant disease resistance gene from the satellite RNA of tobacco ringspot virus. Nature (Lond.) 328:802-805.

7. Harrison, B. D., Mayo, M. A., and Baulcombe, D. C. 1987. Virus resistance in transgenic plants that express cucumber mosaic virus satellite RNA. Nature (Lond.) 328:799-801.

8. Hull, R. 1964. Spread of groundnut rosette virus by Aphis craccivora (Koch). Nature (Lond.) 202:213-214.

9. Hull, R., and Adams, A. N. 1968. Groundnut rosette and its assistor virus. Ann. Appl. Biol. 62:139-145.

10. Jacquemond, M., Amselem, J., and Tefler, M. 1888. A gene coding for a monomeric form of cucumber mosaic virus satellite RNA confers tolerance to CMV. Mol. Plant-Microbe Interact. 1:311-316.

11. Kawchuk, L. M., Lynch, D. R., Martin, R. R., Kozub, G. C., and Farries, B. 1997. Field resistance to the potato leafroll luteovirus in transgenic and somaclone potato plants reduces tuber disease symptoms. Can. J. Plant Pathol. 19:260-266.

12. Kawchuk, L. M., Martin, R. R., and McPherson, J. 1990. Resistance in transgenic potato expressing the potato leafroll virus coat protein gene. Mol. Plant-Microbe Interact. 3:301-307.

13. Keese, P. K., and Gibbs, A. 1992. Origins of genes: "Big bang" or continuous creation. Proc. Natl. Acad. Sci. USA 89:9489-9493.

14. Lomonossoff, G. P. 1995. Pathogen-derived resistance to plant viruses. Annu. Rev. Phytopathol. 33:323-343.

15. Matthews, R. E. F. 1991. Plant Virology, 3rd ed. Academic Press, New York.

16. Miller, W. A., Koev, G., and Mohan, B. R. 1997. Are there risks associated with transgenic resistance to luteoviruses? Plant Dis. 81:700-710.

17. Murant, A. F. 1989. Groundnut rosette assistor virus. AAB Description of Plant Viruses, no. 345. Association for Applied Biologists, Warwick, U.K.

18. Murant, A. F. 1990. Dependence of groundnut rosette virus on its satellite RNA as well as on groundnut rosette assistor luteovirus for transmission by Aphis craccivora. J. Gen. Virol. 71:2163-2166.

19. Murant, A. F., Rajeshwari, R., Robinson, D. J., and Raschke, J. H. 1988. 
A satellite RNA of groundnut rosette virus that is largely responsible for symptoms of groundnut rosette disease. J. Gen. Virol. 69:1479-1486.

20. Naidu, R. A., Bottenburg, H., Subrahmanyam, P., Kimmins, F. M., Robinson, D. J., and Thresh, J. M. 1998. Epidemiology of groundnut rosette virus disease: Current status and future research needs. Ann. Appl. Biol. 132:525-548.

21. Naidu, R. A., Kimmins, F. M., Delfosse, P., Alegbejo, M. D., and Waliyar, F. 1997. Groundnut rosette and peanut clump diseases in West Africa. Pages 49-51 in: Groundnut Virus Diseases in Africa: Summ. Recomm. 6th Meet. Int. Working Group, Agric. Res. Counc. Plant Prot. Res. Inst. D. V. R. Reddy, P. Delfosse, J. M. Lenné, and P. Subrahmanyam, eds. International Crops Research Institute for the Semi-Arid Tropics, Andhra Pradesh, India; and Belgian Administration for Development Cooperation, Belgium.

22. Naidu, R. A., Kimmins, F. M., Deom, C. M., Subrahmanyam, P., Chiyembekeza, A. J., and van der Merwe, P. J. A. 1999. Groundnut rosette: A virus disease affecting groundnut production in sub-Saharan Africa. Plant Dis. 83:700-709.

23. Naidu, R. A., Kimmins, F. M., Holt, J., Robinson, D. J., Deom, C. M., and Subrahmanyam, P. 1999. Spatiotemporal separation of groundnut rosette disease agents. Phytopathology 89:934-941.

24. Nutman, F. J., Roberts, F. M., and Williamson, J. G. 1964. Studies of varietal resistance in the groundnut, (Arachis hypogaea L.) to rosette disease. Rhod. J. Agric. Res. 2:63-77.

25. Okusanya, B. A. M., and Watson, M. A. 1966. Host range and some properties of groundnut rosette virus. Ann. Appl. Biol. 58:377-387.

26. Olorunju, P. E., Kuhn, C. W., Demski, J. W., Misari, S. M., and Ansa, O. A. 1991. Disease reactions and yield performance of peanut genotypes grown under groundnut rosette and rosette-free field environments. Plant Dis. 75:1269-1273.
27. Palukaitis, P., and Roossinck, M. J. 1996. Spontaneous change of a benign satellite RNA of cucumber mosaic virus to a pathogenic variant. Nat. Biotechnol. 14:1264-1268.

28. Reddy, D. V. R., Murant, A. F., Raschke, J. H., Mayo, M. A., and Ansa, O. A. 1985. Properties and partial purification of infective material from plants containing groundnut rosette virus. Ann. Appl. Biol. 107:65-78.

29. Robinson, D. J., Ryabov, E. V., Raj, S. K., Roberts, I. M., and Taliansky, M. E. 1999. Satellite RNA is essential for encapsidation of groundnut rosette umbravirus RNA by groundnut rosette assistor luteovirus coat protein. Virology 254:105-114.

30. Ryabov, E. V., Robinson, D. J., and Taliansky, M. E. 1999. A plant virusencoded protein facilitates long-distance movement of heterologous viral RNA. Proc. Natl. Acad. Sci. USA 96:1212-1217.

31. Scott, K. P., Farmer, M.-J., Robinson, D. J., Torrance, L., and Murant, A. F. 1996. Comparison of the coat protein of groundnut rosette assistor virus with those of other luteoviruses. Ann. Appl. Biol. 128:77-83.

32. Storey, H. H., and Ryland, A. K. 1955. Transmission of groundnut rosette virus. Ann. Appl. Biol. 43:423-432.

33. Storey, H. H., and Ryland, A. K. 1957. Viruses causing rosette and other diseases in groundnuts. Ann. Appl. Biol. 45:319-326.

34. Taliansky, M. E., and Robinson, D. J. 1997. Trans-acting untranslated elements of groundnut rosette virus satellite RNA are involved in symptom production. J. Gen. Virol. 78:1277-1285.

35. Taliansky, M. E., Robinson, D. J., and Murant, A. F. 1996. Complete nucleotide sequence and organization of the RNA genome of groundnut rosette umbravirus. J. Gen. Virol. 77:2335-2345.

36. Yie, Y., Zhao, F., Zhao, Z., Liu, Y. Z., Liu, Y. L., and Tien, P. 1992. High resistance to cucumber mosaic virus conferred by satellite RNA and coat protein in transgenic commercial tobacco cultivar G-140. Mol. PlantMicrobe Interact. 5:460-465. 